\title{
APLIKASI PEMBIAYAAN MURABAHAH PRODUK KPRS DI PERBANKAN SYARI'AH
}

\author{
Marwini \\ (Institut Studi Keislaman Darussalam, Gontor, jln. Raya Siman Km. 6, Ponorogo, \\ email:arwin_ugm@yahoo.com)
}

\begin{abstract}
Abstrak
Ide pendirian bank syari'ah adalah untuk menghindari praktik ribâwi dalam aktifitas ekonomi. Namun bank-bank syari'ah dalam melaksanakan kegiatan usahanya tidak menghapuskan bunga dan membagi risiko, tetapi mempertahankan praktik pembebanan bunga, terbukti bank syari'ah, produk pembiayaan 80 sampai 95 persen menggunakana mekanisme murabahah. padahal yang menjadi karakteristik bank syari'ah adalah harus didasarkan kepada Profit and Loss Sharing (PLS), bukan berdasarkan pada prinsip bunga. Murabahah adalah mirip dengan sistem bunga, karena perubahan dari sistem berbasis bunga menuju sistem mark-up hanyalah sekedar perubahan nama, tanpa mengubah substansi. Dalam kasus ini, pelaksanaan pembiayaan murabahah KPR syari'ah dalam bank syari'ah dilihat mekanisme dan ketentuan akad murabahah telah memenuhi prinsip-prinsip syarî'ah, walaupun dalam penentuan margin dalam transaksi ini masih mengacu kepada komponenkomponen penentuan bunga yang digunakan dalam bank konvensional. Komponen-komponen tersebut cost of found, overhead cost, premi risiko, dan jangka waktu.
\end{abstract}

\footnotetext{
Abstract

The idea of syarî'ah bank establishment is to avoid ribâwi practice in economy activity. However, syarî'ah banks in implementing their bussiness activities do not omit the interest and devide the risks, but keeping the burden interest practice. It is proven by syarî'ah bank which has the cost product from 80 to $95 \%$ using murabahah mechanism. The characteristics of syarî'ah bank must be based on Profit and Loss Sharing (PLS), not based on interest principle. Murabahah resembles with interest system since the change from interest-system to mark-up system is only the change of the name, without changing the substance. In this case, the cost establishment of murabahah of syari ${ }^{\prime} a h$ KPR in syarín bank can be seen from the mechanism and contract
} 
determination of murabahah that have met syarî́ah principles, although in determination of margin in this transaction still refers to the components of interest determination used in konventional bank. Those components are cost of found, overhead cost, premium risk, and its period.

\section{Kata-kata Kunci}

murabahah, perbankan syari'ah, cost of found, overhead cost, premi risiko, jangka waktu

\section{Pendahuluan}

Alasan mendasar ide pendirian bank syari'ah ${ }^{1}$ adalah untuk menghindari praktik ribâwi dalam aktifitas ekonomi. Upaya ini telah dilakukan pada pertengahan tahun 1970an. ${ }^{2}$ Karena sebagian ulama berpendapat bahwa konsep bunga dalam bank konvensional adalah termasuk ribâ. Sedangkan ribâ adalah haram dalam Islam.

Dari alasan tersebut, ada pertanyaan menarik dari Abdullah Saeed, "apakah benar bahwa umat Muslim menghindari bertransaksi pada bank konvensional karena keyakinannya bahwa bunga termasuk ribâ dan diharamkan dalam syarî'ah?3

Hasil penelitian Bank Indonesia bekerjasama dengan berbagai lembaga penelitian perguruan tinggi di empat propinsi di pulau Jawa menunjukkan bahwa pengetahuan masyarakat mengenai keberadaan sistem perbankan syari'ah cukup tinggi (diwakili responden Jawa Barat $88,6 \%$ dan Jawa Tengah/D.I. Yogyakarta 71,2\%), walaupun pemahaman mereka tentang kekhasan sistem perbankan syari'ah itu masih rendah. ${ }^{4}$ Sebagian masyarakat masih menganggap bahwa perbedaan bank syari'ah dengan bank konvensional adalah hanyalah pada persoalan istilah bunga dan bagi hasil. Secara prinsip mereka menganggap sama saja karena meminta imbalan dalam transaksi pembiayaannya yang berupa tambahan atau semacam funds transfer

\footnotetext{
1 Istilah Bank Syari'ah hanya digunakan di Indonesia, sedangkan dalam dunia internasional menggunakan Bank Islam (Islamic Banking).

2 Yahia Abdurrahman, The Art of Islamic Banking and Finance (United States of America: Weley, 2010), hlm. 24

3 Abdullah Seed, Menyoal Bank Syariah, terj. Sunan, cet. Ke-3 (Jakarta: Paramadina, 2006), hlm. xix

${ }^{4}$ Bank Indonesia Direktorat Penelitian dan Pengaturan Perbankan Desember 2000.
} 
price. Padahal dalam ekonomi Islam tidak dikenal adanya time value of money, yang berarti bahwa nilai uang saat ini dengan nilai uang pada masa yang akan datang tidaklah berubah. Uang hanya dipahami sebagai sekedar alat tukar terhadap suatu barang yang dibeli. ${ }^{5}$

Bahkan ilmuan Muslim berpendapat bahwa bank-bank Islam dalam aplikasinya justru bertentangan dengan semangat syarî́ah. Mereka mempertanyakan "apakah bank syari'ah pada praktiknya sudah sesuai dengan semangat awal, yaitu untuk menghapuskan bunga dan risiko ditanggung bersama?' Sutan Remy menyatakan, bahwa bank-bank Islam dalam melaksanakan kegiatan-kegiatan usahanya, tidak menghapuskan bunga dan membagi risiko, tetapi mempertahankan praktik pembebanan bunga. ${ }^{7}$

Abdullah Seed dalam hasil penelitiannya mengatakan bahwa pada praktiknya bank-bank Islam menunjukkan bahwa mereka tidak mampu menghapus bunga dari transaksi-transaksi mereka, yang dipraktikkan dengan beragam samaran dan nama. Lebih jauh, ia menegaskan bahwa tidak ada alasan bagi ekonom Islam telah mengembangkan suatu metode pembiayaan yang bebas dari bunga. Label Islam dalam suatu perbankan Islam tidaklah cukup untuk dikatakan bahwa bank tersebut adalah islami atau tidak, tanpa benarbenar menerapkan prinsip-prinsip syarî'ah secara benar dan sempurna. ${ }^{8}$

Dalam lembaga keuangan atau perbankan syari'ah, produk pembiayaan yang menggunakana mekanisme murabahah mendominasi sekitar 80 sampai dengan 95 persen dari transaksi keuangan yang ada. ${ }^{9}$ Padahal secara teoritis dan sebagai karakteristik bank syari'ah adalah harus didasarkan kepada Profit and Loss Sharing (PLS), bukan berdasarkan pada prinsip bunga. Namun dalam

\footnotetext{
5 Adiwarman Karim, Bank Islam: Analisis Fiqih dan Keuangan, edisi ke-3 (Jakarta: RajaGgrafindo Persada, 2004), hlm. 376

6lihat Amir Muallim, "Lima Aspek Ekonomi Islam yang Diragukan”, dalam Menjawab Keraguan Ekonomi Syari'ah, ed. Amir Muaalim (Yogyakarta: Safiria Insania Press, 2008), hlm. vii

7 Sutan Remy Sjahdeini, Perbankkan Islam dan Kedudukannya dalam Tata Hukum Perbankan Indonesia (Jakarta: Pustaka Utama Grafiti, 1999), hlm. 117.

8 Abdullah Seed, Menyoal Bank Syariah, hlm. 234.

9 Naili Rahmawati, Mekanisme Pembiayaan Murabahah: http:/ / williameaster.files.wordpress.com/2012/03/15_easterly_rahmawati_prp.pdf. diakses tanggal 15 Maret 2012, hlm. 1
} 
praktiknya, bank-bank syari'ah kesulitan menerapkan PLS, karena penuh risiko dan tidak pasti. Untuk menghindari risiko dan ketidakpastian tersebut, adalah murabahah menjadi andalan sebuah produk bank syari'ah, karena secara operasional, transaksi murabahah menggunakan model kontrak "Natural Certainty Contrac", yaitu sebuah kontrak atau akad dalam jual beli yang memberikan kepastian pembayaran, baik dari segi jumlah (amuont), waktunya (timing), mutu (quality), harga (price), atau memberikan cash-flow yang pasti dan gambaran rata-rata profit yang jelas, sehingga bersifat fixed and predetermined. 10 Namun, menurut Abdullah Seed, murabahah adalah mirip dengan sistem bunga, karena perubahan dari sistem berbasis bunga menuju sistem mark-up hanyalah sekedar perubahan nama, tanpa mengubah substansi. ${ }^{11}$

Dari pendapat Seed dapat dilihat bahwa skim murabahah sebagai produk perbankan syari'ah masih terjadi pro dan kontra. Mereka yang setuju terhadap konsep ini berpendapat bahwa konsep mark-up dalam murabahah adalah timbul bukanlah karena tempo pinjaman, melainkan timbul akibat adanya biaya-biaya dalam proses pelayanan. ${ }^{12}$ Sedangkan ulama yang kontra, menganggap produk murabahah merupakan skim yang sama dengan bunga atau lebih mahal dari bunga.

Berdasarkan uraian di atas, semangat historis dioperasikannya perbankan syari'ah yang harus berpegang teguh pada prinsip-prinsip syarî'ah, menghindari ribâ. Namun dalam praktiknya, dari banyak pendapat dan hasil penelitian sebelumnya menyatakan bahwa perbankan syari'ah tidak jauh berbeda dengan bank konvensional. Mereka belum menerapkan prinsip syarî'ah sepenuhnya dan masih menggunakan praktik bunga. Sehingga menimbulkan pertanyaan bagaimana mekanisme transaksi dalam pembiayaan murabahah KPR Syarî'ah dan bagaimana pula metode penentuan margin keuntungan murabahah KPR dalam perbankan syari'ah.

10 Adiwarman Azwar karim, Bank Islam: Analisis Fiqih dan Keuaangan, edisi dua, (Jakarta: PT. RajaGgrafindo Persada, 2004), hlm. 103

11 Seed, Menyoal Bank Syariah, hlm. 146, lihat juga Muhammad, Manajemen Bank Syariah (Yogyakarta: PT. UUP AMP YKPN, 2005), hlm. 139

${ }_{12}$ Marvin K. Lewis dan Latifa M. Abgaoud, Perbankan Syariah, Prinsip, Praktik dan Prospek, terj. Burhan Subrata (Jakarta: Serambi Ilmu Semesta, 2007), hlm. 75. 


\section{Pengertian dan Sejarah Perbankan Syari'ah}

Bank syari'ah adalah lembaga keuangan yang usaha pokoknya memberikan kredit dan jasa-jasa lain dalam lalulintas pembayaran serta peredaran uang yang sistem operasionalnya sesuai dengan prinsip-prinsip syarî́ah.13 Dalam pasal 1 ayat (1) Undang-undang no. 21 tahun 2008 tentang Perbankan Syari'ah didefinisikan bahwa perbankan syari'ah adalah segala sesuatu yang menyangkut tentang bank syari'ah dan unit usaha syari'ah, mencakup kelembagaan dan kegiatan usaha. ${ }^{14}$ Dari definisi tersebut dapat dipahami bahwa perbankan syari'ah adalah meliputi Bank Umum Syari'ah (BUS), Unit Usaha Syari'ah (UUS), dan Pembiayaan Rakyat Syari'ah (BPRS). Pasal 1 ayat (1) Undang-undang perbankan syari'ah menjelaskan bahwa bank syari'ah adalah bank yang menjalankan kegiatan usahanya berdasarkan prinsip syari'ah. Kalau berdasarkan definisi ini dapat dipahami bahwa bank syari'ah adalah hanya meliputi Bank Umum Syari'ah (BUS) dan Bank Pembiayaan Rakyat Syari'ah (BPRS). ${ }^{15}$

Secara historis, embrio berdirinya perbankan syari'ah berawal dari fatwa para ulama terhadap bunga bank sebagai ribâ dan dihukumi haram. Di beberapa negara, bank yang beroperasi dengan menggunakan prinsip syarî'ah dengan sistem bagi hasil, di antaranya adalah Mit Gharmr Mesir (1963), Nasir Sosial Bank (1971), Islamic Development Bank (IDB) pada tahun 1974, Dubai Islamic Bank (1974), Faisal Islamic Bank Sudan (1977), Kwait Finance House (1977), dan beberapa Bank Islam lainnya, seperti Bank Islam Malaysia Berhad pada tahun 1983, yang merupakan pengembangan dari Institusi Investasi Islam Tabungan Haji Malaysia. ${ }^{16}$ Gagasan berdirinya Bank Islam secara kolektif di tingkat internasional telah muncul pada konferensi negara-negara Islam sedunia yang diselenggarakan pada tanggal 21-27 April tahun 1969 di Kuala Lumpur, Malaysia.

${ }^{13}$ Lihat Heri Sudarsono, Bank dan Lembaga Keuanagan Syariah, Deskripsi dan Ilustrasi, edisi 3 (Yogyakarta: Ekononisia, 2008), hlm. 27, lihat juga Hasan Muarif Ambari, et al, Ensiklopedi Islam, jilidI, cet. ke-6 (Jakarta: Icktiar Baru van Hoeve, 1990), hlm. 231

14 Zubairi Hasan, Undang-undang Perbankan Syariah, Titik Temu Hukum Islam dan Hukum Nasional (Jakarta: PT. RajaGrafindo Persada, 2009), hlm. 4

15 Ibid., hlm. 5

16 Ruslan Abdul Ghofur, "Mengembankan Ekonomi Kerakyatan: Beberapa Catatan tentang Praktik Lembaga Keuangan Syariah", dalam Kumpulan Makalah Dosen Perguruan Tinggi Islam Indonesia Peserta Program PETRII 2004-2006, ed. Generasi Baru Peneliti Muslim Indonesia (Jakarta: Australia-Indonesia institute, 2008), hlm. 18 
Marwini

Konferensi tersebut diikuti oleh 19 negara peserta yang menghasilkan keputusan, di antaranya adalah diusulkannya agar membuat bank syari'ah yang bebas dari sistem ribâwwi. ${ }^{17}$ Setelah melalui tiga agenda pembahasan, pada sidang Menteri Luar Negeri negera-negara peserta Organisasi Konferensi Islam (OKI) yang diselenggaran di Karachi, Pakistan pada bulan Desember 1970, di Benghazi, Libya yang diselenggarakan pada bulan Maret 1973 dan di Jeddah pada tahun 1974, menghasilkan keputusan pendirian Islamic Development Bank (IDB). 18 Kemudian berdirinya IDB ini menjadi pelopor dan mendorong berdirinya bank Islam di beberapa Negara di dunia (pada pereode 1970-1980an), seperti Mesir, Sudan, Pakistan, Iran, Malaysia, Turki, dan negara-negara yang penduduknya Muslim minoritas, seperti Inggris, Swiss, Singapura, Denmark dan juga termasuk Indonesia.

Di Indonesia, wacana Bank Syari'ah telah dikemukakan pada acara seminar nasional Hubungan Indonesia-Timur Tengah pada tahun 1974 dan pada acara Seminar Internasional yang diselenggarakan oleh Lembaga Studi Ilmu-ilmu Kemasyarakatan (LSIK) pada tahun $1976 .{ }^{19}$ Pada tahun 1980-an, para aktivitis muda Muslim pun sudah aktif melakukan kajian tentang ekonomi syarî́ah walaupun pada tempat-tempat terbatas, seperti yang pernah dilakukan di BMT Salman, Bandung. ${ }^{20}$

Walaupun gagasan tentang perbankan syari'ah ini mulai intensif dibahas pada acara workshop tentang "Bunga bank dan Perbankan" yang diselenggarakan oleh Majlis Ulama Indonesia (MUI) pada tanggal 19-22 Agustus 1990 di Bogor yang mengasilkan sebuah rekomendasi berdirinya perbankan syari'ah di Indonesia. ${ }^{21}$ Bank yang beroperasi dengan menggunakan prinsip syarîah pertama di Indonesia adalah Bank Muamalah Indonesia (BMI) yang beroperasi pada tanggal 1 Mei tahun 1992.22

\section{Aplikasi Pembiayaan Murabahaha KPR Syari'ah}

17 Lihat Sudarsono, Bank dan Lembaga Keuangan Syariah, hlm. 29

18 Ibid.

19 Ibid., hlm. 30

${ }^{20}$ Hasan, Undang-undang Perbankan Syariah, hlm. 9

${ }^{21}$ Ghofur, Mengembankan Ekonomi Kerakyatan, hlm. 16

22 Ibid. 
Salah satu pembiayaan yang paling banyak digunakan oleh perbankan syari'ah adalah pembiayaan jual-beli murabahah. Transaksi ini dalam sejarah Islam telah dilakukan pada masa Rasulullah dan para sahabatnya. Sejak awal munculnya dalam kajian figh, kontrak ini tampaknya telah digunakan murni untuk tujuan bisnis.

Kata murabahah sendiri secara etimologi berasal dari kata rabiha-yarbahu yang mempunyai arti untung. ${ }^{23}$ Kata murabahah berasal dari kata ribh , yang berarti perolehan, keuntungan, atau tambahan, ${ }^{24}$ yang secara bahasa berbentuk mutual yang bermakna saling. Jadi dalam konteks bisnis makna dari kata murabahah adalah saling mendapatkan keuntungan.

Murabahah menurut ulama figh adalah akad jual beli atas barang tertentu. ${ }^{25}$ Menurut definisi lain, murabahah adalah jual-beli barang dengan harga asal (pokok) dan ditambah keuntungan yang disepakati antara pihak nasabah dan lembaga keuangan, atau dengan redaksi lain, murabahah adalah akad jual beli barang dengan menyatakan harga perolehan dan keuntungan (margin) yang disepakati oleh penjual dan pembeli.26

Menurut Hanafi, al-Marghinani, sebagaimana yang dikutip oleh Ayyub, murabahah didefinisikan sebagai "penjualan barang apa pun dengan harga pembelian yang ditambah dengan jumlah harga yang tetap sebagai keuntungan", ${ }^{27}$ Ibn Qudama, seorang ahli figh madzhab Hanbali, mendefinisikan murabahah adalah sebagai penjualan pada biaya modal tambah dengan keuntungan yang diketahui. 28

Walaupun dari beberapa definisi murabahah yang secara redaksional berbeda, namun pada esensinya mempunyai pengertian yang sama, yaitu transaksi jual beli barang dengan mencantumkan harga pokok pembelian dan ditambah dengan keuntungan (margin)

23 'Abd al-Qadîr al-Râzi, Mukhtar al-Shihhah, (Lebanon: Maktabah Lubnan Nâsyirûn 1995), hlm. 97

24 Muhamaad Ayyub, Understanding Islamic Finance (Jakarta: PT. Gramedia Pustaka Utama, 2009), hlm. 337

${ }_{25}$ Habib Nazir Muhammad Hasanuddin, Ensiklopedi Ekonomi dan Perbankan Syariah, (Bandung: Kafa Publishing, 2008), hlm. 459.

${ }^{26}$ Sudarsono, Bank dan Lembaga Keuangan Syariah, hlm. 69, dan juga lihat Karim, Bank Islam, 113.

${ }^{27}$ Ayyub, Understanding, hlm. 337

28 Ibid., hlm. 338 
yang disepakati dalam transaksi jual-beli tersebut. Dengan demikian, karakteristik dari akad murabahah dalam transaksi jual beli penjual harus memberitahukan harga pokok kepada pembeli dan menyatakan jumlah keuntungan yang ditambahkan pada biaya tersebut. Penambahan biaya margin laba tersebut dapat mencakup apa saja yang dipilih penjual untuk dimasukkan kedalam harga. Jadi, di samping harga pokok suatu barang yang dimasukkan dalam proses transaksinya, penjual dapat menambahkan beban tertentu sebagai pengganti seperti resiko. ${ }^{29}$

Murabahah termasuk salah satu pola akad jual beli, ${ }^{30}$ yang secara tersurat tidak disebut secara langsung dalam al-Qur'an dan Hadist. Walaupun demikian, Mâlik dan al-Syâfi'î berpendapat, sebagaimana yang dikutip oleh Abdullah Saeed, ${ }^{31}$ bahwa jual beli murabahah adalah halal. Alasan Mâlik atas keabsahan transaksi murabahah didasarkan kepada praktik penduduk Madinah. Ada kesepekatan pendapat di Madinah tentang keabsahan seseorang yang membelikan pakaian di kota, dan kemudian ia membawanya ke kota lain untuk menjualnya kembali dengan keuntungan yang disepakati. ${ }^{32}$

Sedangkan alasan al-Syâfi'î atas keabsahan transaksi murabahah adalah bahwa jika seseorang menunjukkan suatu barang kepada seseorang dan berkata, "belikan barang (seperti) ini untukku dan aku akan memberimu keuntungan sekian", lalu orang itu membelinya, maka jual beli tersebut adalah sah. ${ }^{33}$

Syafi'e Antonio, ${ }^{34}$ menjadikan dasar hukum murabahah adalah didasarkan kepada keumuman lafazh al-Qur'an surat al-Baqarah (2): 29 tentang jual beli "dan Allah telah menghalalkan jual beli dan mengharamkan ribâ" 35 dan al-Qur'an surat al-Nisâ (4): 29 tentang

${ }^{29}$ Frank E Vogel, Hukum Keuangan Islam, Konsep, Teori dan Praktik, terj. Syahadah Karim (Bandung: Nusamedia, 2007), hlm. 222

30 Ascarya, Akad \& Produk Bank Syariah (Jakarta: Rajawali Press, 2011), hlm. 81

31 Lihat Saeed, Menyoal Bank Syariah, hlm. 119

32 Ibid., hlm. 120

33 Ibid.

34 Muhammad Antonio Syafi'e, Bank Syariah: Dari Teori ke Praktik (Jakarta: Penerbit Gema Insani, 2001), hlm. 102; lihat juga M. Yazid Afandi, Figh Muamalah dan Implementasinya dalam Lembaga Keuangan Syariah (Yogyakarta: Penerbit Logung Pustaka, 2009), hlm. 87.

35 Al-Qur`an Surat al-Baqarah (2): 275. 
perniagaan "Hai orang-orang yang beriman, janganlah kamu saling memakan harta sesamamu dengan jalan yang batil, kecuali dengan jalan perniagaan yang Berlaku dengan suka sama-suka di antara kamu". ${ }^{36}$ Sedangkan Hadits Nabi yang dijadikan dasar hukum murabahah adalah Hadits yang diriwayatkan oleh Ibn Mas'ûd; "bahwa ia tidak memandang masalah terhadap jual beli yang dilakukan dengan menghitung setiap sepuluh mendapatkan laba satu atau dua dirham".

Secara tersirat hadis ini mengisyaratkan tentang bentuk jual beli yang menghitung harga pokok pembelian dengan laba (margin) yang akan diperoleh. Sebagaimana cerita Ibn Abbas, yang dikutip oleh Yazid Affandi, ${ }^{37}$ Ibnu Abbâs mengatakan bahwa menjual barang dengan memberitahukan harga pokoknya dan meminta keuntungan tertentu dari harga barang pokok yang dijual tersebut merupakan jual beli yang diperbolehkan. Maka, pola jual beli yang semacam ini disebut jual beli murabahah.

Ada beberapa persyaratan dalam transaksi jual-beli dengan akad murabahah yang harus diperhatikan, ${ }^{38}$ yaitu: (1) mengetahui biaya modal, di mana penjual harus memberitahu pembeli perihal biaya modal yang dikeluarkan, karena hal ini menjadi syarat sahnya jual beli, dan jika biaya modal ini tidak dapat diketahui, maka proses jual beli ini batal atau tidak sah; (2) besarnya keuntungan harus diketahui, penjual diwajibkan memberitahu kepada pembeli tentang besarnya keuntungan yang diambil, karena keuntungan merupakan dari harga dan mengetahui harga merupakan syarat dari sahnya jual beli; (3) modal harus serupa (sejenis), dalam hal ini modal dapat diketahui dengan nilai, seperti timbangan atau klasifikasi yang serupa, karena pengertian murabahah adalah jual-beli barang dengan harga yang disepakati di awal dengan menambahkan keuntungan, maka biaya modal pertama harus serupa dengan biaya yang diambil untuk tambahan keuntungan; (4) kontrak murabahah bebas dari praktik ribâ, karena murabahah merupakan jual beli dengan harga awal dan dengan tambahan keuntungan, apabila keuntungan tersebut ada unsur ribâ, maka tidak dinamakan keuntungan, akan tetapi

\footnotetext{
36 Al-Qur`an Surat al-Nisâ' (4): 29.

${ }^{37}$ Lihat Affandi, Fiqih Muamalah,hlm. 89

38 Wahbah al-Zuhayli, Al-Figh al-Islâmi wa Adillatuhu, cet. I, jilid. V, (Beirut: Dâr alFikr, 1997), hlm. 3768.
} 
dinamakan ribâ; ${ }^{39}$ (5) kontrak jual-beli pertama harus sah, jika kontrak pertama batal atau tidak sah maka tidak bisa dilakukan murabahah, karena kontrak (akad) murabahah adalah jual-beli dengan harga keuntungan. Jual-beli yang tidak sah mengakibatkan tetapnya kepemilikan dengan nilai barang bukan dengan harga yang tertentu, hal itu disebabkan karena rusaknya definisi; (7) penjual harus memberitahukan kepada pembeli perihal barang, bila terjadi cacat pada barang yang sudah dibeli, maka penjual harus memberitahu kepada pembeli tentang keadaan barang gtersebut. Ini sangat urgen dalam transaksi kontrak (akad) murabahah.40

Wahbah al-Zuhayli mengatakan bahwa di dalam transaksi murabahah ada beberapa persyaratan yang harus dipenuhi, antara lain adalah:41 (1) diketahuinya harga pokok dalam jual beli murabahah, penjual diharuskan untuk memberitahukan secara jelas harga pokok atau harga awal dari suatu barang yang akan dijual kembali kepada pembeli untuk menghindari terjadi transaksi yang tidak jelas (gharâr) di antara kedua belah pihak; (2) diketahuinya margin keuntungan yang ditetapkan pihak penjual ketika melakukan transaksi dengan pembeli diwajibkan untuk menjelaskan berapa dan bagaimana margin keuntungan yang akan ditetapkan dari barang yang dijual, dan hal ini merupakan unsur yang urgen untuk mendukung terjadinya transaksi yang saling rela ('antarâdlin) di antara kedua belah pihak; (3) harga awal (pokok) adalah sesuatu yang dapat diukur, dihitung dan ditimbang dengan nilai, baik ketika terjadi transaksi jual beli yang pertama ataupun sesudahnya.

Secara umum para ulama berbeda pendapat tentang biaya yang dapat dibebankan pada harga jual barang terkait dengan markup dalam transaksi murabahah. ${ }^{42}$ Pendapat para madzhab tersebut adalah sebagai berikut: (1) Madzhab Mâlikî membolehkan adanya biaya-biaya yang langsung dan tidak langsung yang terkait dengan transaksi jual beli dengan ketentuan dapat memberikan nilai tambah

39 Wahbah al-Zuhayli, Al-Mu'âmalat al-Mâliyat al-Mu'âsyirah (Beirut: Dâr Fikr, 2002), hlm. 68 .

40 Antonio, Bank Syariah, hlm. 102

41 Lihat al-Zuhayli, Figh al-Islâmi, hlm. 3768.

42 Naili Rahamawati, Mekanisme Pembiayaan Murabahah: www.yahooo.com/mekanisme pembiayaan murabah. diakses pada tanggal 19 Mei 2012. 
pada barang tersebut; (2) Madzhab Syâfi'î membolehkan untuk membebankan biaya-biaya yang secara umum timbul dalam suatu transaksi jual-beli, kecuali biaya tenaga kerjanya sendiri karena komponen ini sudah termasuk dalam keuntungannya. Begitu pula dengan biaya-biaya yang tidak menambah nilai barang tidak boleh dimasukkan sebagai komponen biaya; (3) Madzhab Hanbalî mengatakan bahwa semua biaya yang langsung maupun tidak langsung dapat dibebankan pada harga jual selama biaya-biaya itu harus dibayarkan kepada pihak ketiga dan dapat menambah nilai barang yang dijual tersebut; (4) Madzhab Hanafî membolehkan untuk membebankan biaya-biaya yang secara umum dapat timbul dalam suatu transaksi jual-beli, dan tidak boleh mengambil keuntungan berdasarkan biaya-biaya yang semestinya ditanggung oleh si penjual.

\section{Aplikasi Pembiayaan Murabahah pada Bank Syari'ah}

Secara yuridis, produk pembiayaan murabahah dalam perbankan syari'ah didasarkan pada: ${ }^{43}$ (1) pada pasal 1 ayat 13 Undang-undang nomor 10 tahun 1998 tentang perbankan; (2) PBI No. 9/19/PBI/2007 Jo. PBI No. 10/16/PBI/2008 tentang pelaksanaan prinsip syarî'ah dan kegiatan penghimpunan dana dan penyaluran dana serta pelayanan jasa bank syari'ah; (3) Peraturan Bank Indonesia Nomor 10/17/PBI/2008 tentang Produk Bank Syari'ah dan Unit Usaha Syari'ah; (4) pasal 19 Undang-undang No. 21 Tahun 2008 tentang perbankan syari'ah yang mengatur mengenai kegiatan usaha Bank Umum Syari'ah yang salah satunya adalah pembiayaan murabahah; (5) ketentuan pembiayaan murabahah dalam praktik perbankan syari'ah di Indonesia dijelaskan dalam Fatwa Dewan Syari'ah Nasional (DSN) No. 04/DSN-MUI/IV/2000 tentang Murabahah.

a. Dalam Fatwa Dewan Syari'ah Nasional (DSN) No. 04/DSN-MUI/IV/2000 ketentuan pembiayaan murabahah berupa:44 (1) ketentuan umum murabahah dalam bank syari'ah, (2) ketentuan murabahah kepada nasabah; (3) jaminan dalam murabahah; (4) hutang

\footnotetext{
43 Bagya Agung Prabowo, Aspek Hukum Pembiayaan Murabahah pada Perbankan Syariah (Yogayakarta: UII Press, 2012), hlm. 29.

44 Lihat Fatwa Dewan Syari'ah Nasional (DSN) No. 04/DSN-MUI/IV2000 tentang Murabahah.
} 
dalam murabahah; (5) penundaan pembayaran dalam murabahah; (6) bangkrut dalam murabahah.

Ketentuan umum murabahah dalam Bank Syari'ah mencakup: (1) bank dan nasabah harus melakukan akad murabahah yang bebas ribâ; (2) barang yang diperjualbelikan tidak diharamkan oleh syarî́ah Islam; (3) bank membiayai sebagian atau seluruh harga pembelian barang yang telah disepakati kualifikasinya; (4) bank membeli barang yang diperlukan nasabah atas nama bank sendiri, dan pembelian ini harus sah dan bebas dari ribâ; (5) bank harus menyampaikan semua hal yang berkaitan dengan pembelian, misalnya jika pembelian dilakukan secara hutang; (6) bank kemudian menjual barang tersebut kepada nasabah berikut biaya yang diperlukan; (7) nasabah membayar harga barang yang telah disepakati tersebut pada jangka waktu tertentu yang telah disepakati; (8) untuk mencgah terjadinya penyalahgunaan atau kerusakan akad tersebut, pihak bank dapat mengadakan perjanjian khsusus dengan nasabah; (9) jika bank hendak mewakilkan kepada nasabah untuk membeli barang dari pihak ketiga, akad jual beli murabahah harus dilakukan setelah barang, secara prinsip, menjadi milik bank.

Ketentuan murabahah kepada nasabah, meliputi: (1) nasabah mengajukan permohonan dan janji pembelian suatu barang atau asset kepada bank; (2) jika bank menerima permohonan tersebut, ia harus membeli terlebih dahulu aset yang dipesannya secara sah dengan pedagang; (3) bank kemudian menawarkan aset tersebut kepada nasabah dan nasabah harus menerima atau membelinya sesuai dengan janji tersebut mengikat; kemudian kedua belah pihak harus membuat kontrak jual beli; (4) dalam jual beli ini bank dibolehkan meminta nasabah untuk membayar muka saat menandatangani kesepakatan awal pemesanan; (5) jika nasabah kemudian menolak membeli barang tersebut, biaya riil bank harus dibayar dari uang muka tersebut; (6) jika nilai uang muka kurang dari kerugian yang harus ditanggung oleh bank, bank dapat meminta kembali sisa kerugiannya kepada nasabah; (7) jika uang muka memakai kontrak urbun sebagai alternatrif dari uang muka, maka: (a) jika nasabah memutuskan untuk membeli barang tersebut, ia tinggal membayar sisa harga; (b) jika nasabah batal membeli, uang muka menjadi milik bank maksimal sebesar kerugian yang ditanggung oleh bank akibat 
pembatalan tersebut; dan jika uang muka tidak mencukupi, nasabah wajib melunasi kekurangannya.

Jaminan dalam murabahah dibolehkan, agar nasabah serius dengan pesanannya, dan bank dapat meminta nasabah untuk menyediakan jaminan yang dapat dipegang.

Dalam hal hutang dalam murabahah, secara prinsip, penyelesaian utang nasabah dalam transaksi murabahah tidak ada kaitannya dengan transaksi lain yang dilakukan nasabah dengan pihak ketiga atas barang tersebut. Jika nasabah menjual kembali barang tersebut dengan keuntungan atau kerugian, ia tetap berkewajiban untuk menyelesaikan utangnya kepada bank. Jika nasabah menjual barang tersebut sebelum masa anggsuran berakhir, ia tidak wajib segera melunasi seluruh angsurannya. Jika penjualan barang tersebut menyebabkan kerugian, nasabah tetap harus menyelesaikan utangnya sesuai dengan kesepakatan awal. Ia tidak boleh memperlambat pembayaran angsuran atau meminta kerugian itu diperhitungkan.

Dalam hal penundaan pembayaran dalam murabahah, nasabah yang memiliki kemampuan tidak dibenarkan menunda penyelesaian utangnya. Jika nasabah menunda-nunda pembayaran dengan sengaja, atau jika salah satu pihak tidak menunaikan kewajibannya, maka penyelesaiannya dilakukan melalui Badan Arbitrase setelah tidak tercapai kesepakatan melalui musyawarah. Jika nasabah telah dinyatakan pailit dan gagal menyelesaikan utangnya, bank harus menunda tagihan utang sampai ia menjadi sanggup kembali, atau berdasarkan kesepakatan.

\section{Produk Murabahah dalam Perbankan Syari'ah}

Dalam figh ada dua jenis murabahah ${ }^{45}$ yang menjadi akad transaksi jual beli yaitu murabahah tanpa pesanan dan murabahah berdasarkan pesanan. Murabahah tanpa pesanan adalah penyediaan barang yang akan ditransaksikan dilakukan tanpa adanya pemesan. Sedangkan jenis murabahah berdasarkan pesanan adalah suatu penjualan dimana dua pihak atau lebih bernegoiasasi dan berjanji satu sama lain untuk melaksanakan suatu kesepakatan bersama, di mana nasabah, sebagai pemesan, meminta kepada bank untuk

45 Wiroso, Jual Beli Murabahah (Yogyakarta: UII Press, 2005), hlm. 37-38 
membeli aset yang kemudian dimiliki secara sah oleh pihak kedua. Nasabah berjanji kepada bank untuk membeli aset tersebut dan memberikan keuntungan atas pesanan tersebut. Biasanya yang banyak diadopsi menjadi produk pembiayaan murabahah dalam perbankan syari'ah adalah produk pembiayaan murabahah berdasarkan pesanan, karena dalam peraturannya perbankan tidak boleh menyediakan barang untuk perjualbelikan.

\section{Mekanisme Pembiayaan Murabahah dalam Perbankan Syari'ah}

Pada awalnya, murabahah merupakan konsep jual beli yang sama sekali tidak ada hubungannya dengan pembiayaan. Kemudian pola jual beli ini berkembang dan diadopsi oleh perbankan syari'ah dengan menambah beberapa konsep lain menjadi produk pembiayaan. ${ }^{46}$

Pada prinsipnya, transaksi murabahah adalah pengadaan barang menjadi tanggung jawab bank sebagai penjual, dan barang harus berada dalam penguasaan dan tanggungan bank selama kewajiban nasabah kepada bank belum selesai. Dalam mekanisme pembiayaan murabahah, ada beberapa hal yang perlu diperhatikan. Hal-hal tersebut adalah sebagai berikut: 47 Pertama, pembiayaan murabahah bukan pola pembiayaan yang berprinsip bunga, melainkan pembiayaan jual beli komoditas dengan harga tangguh yang meliputi harga pokok dan ditambah margin keuntungan yang telah disepakati bersama. Kedua, pembiayaan murabahah harus memenuhi syaratsayarat sahnya jual beli. Ketiga, murabahah dapat digunakan sebagai bentuk pembiayaan apabila nasabah memerlukan dana tersebut dan digunakannya untuk pembelian suatu barang komoditas/barang. Misalnya jika nasabah membutuhkan uang untuk membeli sepeda motor, maka bank dapat menjual sepeda motor yang dibutuhkan tersebut kepada nasabah dengan bentuk pembiayaan murabahah.

Keempat, pemberi pembiayaan (bank) harus telah memiliki komoditas atau barang sebelum dijual kepada nasabah pemesan. Kelima, barang tersebut harus sudah dalam penguasaan pemberi pembiayaan (bank) secara fisik atau konstruktif. Keenam, untuk memenuhi prinsip-prinsip syarî́ah dalam ber-murabahah, pemberi

46 Ascarya, Akad, hlm. 82

47 Ibid., hlm. 85-88 
pembiayaan membeli komoditas atau barang dan menyimpan dalam kekuasaanya atau membeli barang tersebut melalui pihak ketiga sebagai agen sebelum bank menjual (dengan bentuk pembiayaan) kepada nasabah. Namun diperbolehkan bagi pemberi pembiayaan untuk memanfaatkan nasabah sebagai agen untuk membeli barang yang diperlukan dengan atas nama pemberi pembiayaan dan mengambil alih penguasaan barang. Kemudian nasabah membeli barang tersebut dari pemberi pembiayaan dengan harga tangguh. Penguasaan nasabah atas barang tersebut kapasitasnya sebagai agen dari pemberi pembiayaan. Dalam kapasitas ini, nasabah hanya sebagai trustee, sedangkan kepemilikan dan risiko barang tersebut ada pada pemberi pembiayaan. Tetapi setelah nasabah membeli barang tersebut dari pemberi pembiayaan, maka kepemilikan dan risiko atas barang tersebut ada pada tangan nasabah.

Ketujuh, sesuai dengan prinsip-prinsip syarî'ah yang telah dijelaskan di atas, Lembaga Keuangan Syari'ah (Bank) dapat menggunakan murabahah dalam pola pembiayaan dengan menggunakan prosidur sebagai berikut: (1) nasabah dan pihak bank syari'ah menandatangani perjanjian umum ketika bank berjanji untuk menjual dan nasabah berjanji untuk membeli barang tertentu dari waktu ke waktu pada tingkat margin tertentu yang menjadi tambahan harga pokok barang; (2) ketika barang tertentu dibutuhkan oleh nasabah, maka bank syari'ah dapat menunjuk nasabah sebagai agennya untuk membeli yang dimaksud dengan atas nama bank syari'ah, dan perjanjian keagenan tersebut ditandatangai kedua belah pihak tersebut; (3) nasabah membeli barang yang dibutuhkan tersebut dengan atas nama pemberi pembiayaan (bank syari'ah) dan sebagai agen dari pemberi pembiayaan (bank syari'ah); (4) nasabah memberitahukan kepada pemberi pembiayaan (bank syari'ah) bahwa barang telah dibeli atas nama permberi pembiayaan (bank syari'ah) dan pada saat itu juga pemberi pembiayaan (bank syari'ah) menyampaikan kepada nasabah untuk membeli barang tersebut; (5) kemudian, proses transaksi disepakati dan kepemilikan serta risiko barang beralih kepada tangan nasabah.

Kedelapan, bank syari'ah dapat meminta kepada nasabah untuk menyediakan keamanan dengan mendatangani nota kesanggupan sesudah jual beli dilaksanakan. Kesembilan, apabila terjadi wan prestasi oleh nasabah dalam pembayaran yang jatuh tempo, maka harga tidak 
boleh dinaikkan. Namun, jika perjanjian awal telah disepakati bahwa nasabah harus memberi infak untuk dana sosial, maka nasabah harus memenuhi janji tersebut dan bank syari'ah menyalurkannya atas nama nasabah.

Dalam kasus pembiayaan KPR Syari'ah yang dilakukan oleh perbankan syari'ah adalah mempunyai ketentuan-ketentuan pokok yang harus disepakati dan tertulis dalam klausul kontrak pembiayaan KPR Syari'ah. ${ }^{48}$ Ketentuan tersebut adalah sebagai berikut: Pertama, Harga beli adalah sejumlah uang yang harus dibayar oleh bank kepada pemasok/pengembang untuk membeli rumah yang dipesan nasabah ditambah (termasuk) biaya-biaya langsung yang dilekeluarkan oleh bank untuk membeli rumah yang dipesan nasabah tersebut. ${ }^{49}$

Kedua, uang muka adalah sejumlah uang yang besarnya ditetapkan oleh bank dan disetujui oleh nasabah yang harus dibayarkan terlebih dahulu oleh nasabah kepada bank sebagai salah satu syarat yang harus dipenuhi nasabah untuk memperoleh pembiayaan murabahah dari bank. 50 Ketiga, pokok pembiayaan adalah kekurangan dari uang muka yang telah dibayar didepan oleh nasabah kepada bank dari harga beli bank kepada pemasok/pengembang. Keempat, margin keuntungan adalah jumlah uang yang wajib dibayar nasabah kepada bank sebagai imbalan atas pembiayaan yang diberikan oleh bank, yang merupakan selisih antara harga jual dengan harga beli. ${ }^{51}$

Kelima, harga jual adalah harga beli ditambah margin keuntungan bank yang ditetapkan oleh bank dan disetujui/disepakati oleh nasabah yang merupakan jumlah pembiayaan KPR Syari'ah.52 Keenam, biaya administrasi adalah biaya-biaya yang dikeluarkan oleh bank selama proses pembiayaan berlangsung. Ketujuh, jenis pembiayaan adalah akad yang digunakan dalam pembiayaan KPR Syari'ah.

48 Lihat Contoh kontrak (akad) dan ketentuan-ketentuannya yang telah ditandatangani antara bank dan nasabah yang dikeluarkan oleh BTN Syari'ah.

49 Pasal (2), ayat (4)

50 Ibid., ayat (20)

${ }^{51}$ Ibid., ayat (9)

52 Ibid., ayat (5) 
Kedelapan, penggunaan pembiayaan. Yang dimaskud dengan penggunaan pembiayaan adalah pembiayaan yang diberikan oleh bank kepada nasabah diperuntukan untuk pembelian rumah. Kesembilan, jangka waktu adalah periode pembiayaan yang telah disepakati antara bank dan nasabah. Kesepuluh, jatuh tempo pembiayaan adalah batas akhir kewajiban nasabah dalam melunasi angsuran. Kesebelas, angsuran perbulan adalah sejumlah uang untuk pembayaran jumlah harga jual yang wajib dibayar secara bulanan oleh nasabah sebagaimana ditentukan dalam akad ini. Keduabelas, denda tunggakan adalah suatu sangsi atas adanya tunggakan, yang dinyatakan dan diperhitungkan dalam prosentase atau jumlah tertentu atas jumlah tunggakan. 53

Ketigabelas, jenis jaminan adalah jaminan yang bersifat materiil maupun immateriil untuk mendukung keyakinan bank atas kemampuan dan kesanggupan nasabah untuk melunasi utang murabahah sesuai akad. ${ }^{54}$ Keempatbelas, letak jaminan adalah tempat di mana barang yang jaminkan itu berada. Kelimabelas, bukti kepemilikan jaminan adalah sartifikat atau surat kepemilikan atas barang yang dijadikan jaminan tersebut. Keenambelas, luas bangunan/tanah jaminan adalah mengambarkan besaran luas bangunan atau tanah yang dijadikan jaminan tersebut. Ketujuhbelas, pemasok/pengembang adalah pihak yang ditunjuk dan/atau disetujui bank untuk menyediakan/mengadakan dan menyerahkan rumah yang dipesan dan dijual kepada nasabah. ${ }^{55}$

\section{Metode Penentuan Margin Murabahah dalam Perbankan Syari'ah}

Penentuan margin keuntungan murabahah pembiayaan KPR Syari'ah adalah dengan mempertimbangkan beberapa aspek, yaitu:56 Pertama, Cost of Found (COF). Cost of Found (COF) adalah semua biaya yang dikeluarkan bank untuk mendapatkan dana, yaitu biaya bunga dana dan biaya promosi dana. Biaya bunga adalah semua biaya dana yang dibayarkan kepada nasabah simpanan baik dalam bentuk giro, deposito, dan tabungan. Ada dua metode perhitungan biaya dana

\footnotetext{
53 Ibid., ayat (3)

54 Ibid., ayat (6)

55 Ibid., ayat (11)

56 Kuncoro dan Suharjono, Manajemen Perbankan Teori dan Aplikasi (Yogyakarta: BPFE UGM, 2002), hlm. 205-305.
} 
(cost of found) yang umum digunakan yaitu historical cost dan margin cost. Historical cost adalah perhitungan yang didasarkan kepada biaya dana riil yang dikeluarkan. Sedangkan marginal cost adalah perhitungan yang didasarkan pada biaya dana dari dana yang paling murah diperoleh di pasar. Beban bunga merupakan komponen perhitungan harga pokok dana yang akan dikenakan kepada debitur. Semakin tinggi beban bunga yang diberikan akan mempengaruhi semakin tingginya bunga kredit yang dikenakan kepada nasabah debitur. 57 sedangkan biaya promosi dana adalah biaya yang dikeluarkan untuk tujuan memperlancar pengerahan dana, seperti biaya periklanan, biaya undian, hadiah, dan lain sebagainya.

Kedua, premi risiko. Premi risiko perusahaan atau debitur yang mencerminkan risiko adalah berkaitan dengan debitur tertentu, merupakan sebuah antisipasi terhadap penghapusan pinjaman, menutupi pinjaman non lancar dan juga ada kemungkinan dipengaruhi oleh struktur pinjaman. Penanaman dana dalam aktiva produktif terutama dalam bentuk kredit memiliki potensi risiko yang yang dapat menimbulkan kerugian bank. Oleh karena itu, faktor risiko dan biaya-biaya lain yang menjadi komponen menjadi penentu besarnya tingkat bunga kredit yang dikenakan kepada nasabah dibetur. Premi risiko dapat diketahui berdasarkan pengalaman bank dalam mengelola kredit, yaitu dengan melakukan penilaian terhadap kualitas kredit. Semakin besar jumlah kredit yang bermasalah maka semakin tinggi risiko yang dihadapi oleh bank. Faktor risiko sebagai salah satu komponen penentuan tingkat bunga kredit dapat dihitung dengan menggunakan metode pembentukan cadangan penghapusan kredit yang dikaitkan dengan persentase tertentu terhadap kualitas atau kolektifitas kredit yang dibagi dengan rata-rata outstanding loan (saldo debet).

Ketiga, overhead cost. Overhead adalah semua biaya yang dikeluarkan bank dalam kegiatan menghimpun dana dan berbagai sumber yang menjadi beban rugi laba, di antaranya adalah beban personalia, administrasi, dan beban lainnya.

Keempat, jangku waktu tempo. Jangku waktu tempo kredit yang lebih panjang cenderung memiliki risiko lebih tinggi, yaitu

${ }^{57}$ Ibid. 
ketidakpastian terhadap pelunasan kredit dari pembayaran bunga dan pokok. Dengan demikian, semakin panjang jangka waktu kredit maka semakin tinggi pula tingkat bunga kredit yang dibebankan bank kepada nasabah. Komponen jangka waktu ini menjadi komponen dalam penentuan margin keuntungan murabahah KPR Syari'ah Menurut salah satu nasabah pembiayaan murabahah, semakin panjang periode waktu pembiayaan murabahah KPR semakin tinggi pula margin yang dibebankan kepada nasabah. 58

\section{Kesimpulan}

Dari uraian di atas dapat disimpulkan bahwa produk pembiayaan murabahah KPR Syari'ah mempunyai ketentuanketentuan pokok yang mengatur mekanisme produk pembiayaan murabahah KPR syari'ah. Kemudian dilihat dari syarat rukun akad, telah memenuhi syarat-rukun sahnya akad jual beli. Prosedur yang dilakukan dalam mekanisme Pembiayaan KPR Syari'ah adalah bank sebagai penjual barang telah sesuai dengan prinsip jual beli murabahah, yaitu memberitahukan secara jujur harga pokok dan ditambah margin keuntungan.

Penentuan margin keuntungan murabahah pembiayaan KPR Syari'ah menggunakan komponen cost of found, overhead cost, premi risiko, dan jangka waktu. Komponen-komponen ini juga digunakan untuk menghitung bunga kredit di bank konvensional. Oleh karena komponen yang digunakan dalam menentukan margin murabahah Pembiayaan KPR Syari'ah adalah kurang tepat digunakan dalam bank syari'ah, karena cenderung kepada praktik ribâ dalam bank konvensional.

\section{Daftar Pustaka:}

Abdurrahman, Yahia. The Art of Islamic Banking and Finance. United States of America: Weley, 2010.

Afandi, M. Yazid. Figh Muamalah dan Implementasinya dalam Lembaga Keuangan Syariah. Yogyakarta: Penerbit Logung Pustaka, 2009.

Ambari, Hasan Muarif. et al. Ensiklopedi Islam, jilidI, cet. ke-6. Jakarta: Icktiar Baru van Hoeve, 1990.

\footnotetext{
58 Wawancara dengan Sobirin, nasabah pembiayaan murabahah KPR BTN Syari'ah, pada tanggal 28 Juni 2012 pukul 15.00 WIB.
} 
Anwar, Syamsul. Hukum Perjanjian Syariah: Studi Tentang Teori Akad dalam Fikih Muamalah, Jakarta: Rajawali Press, 2010.

Ascarya. Akad \& Produk Bank Syariah. Jakarta: Rajawali Press, 2011.

Ayyub, Muhammad. Understanding Islamic Finance. Jakarta: PT. Gramedia Pustaka Utama, 2009.

Bahjatullah, Qi Mangku. Pembiayaan Murabahah dalam Wacana Fikih dan Perbankan Syariah (Tesis Program Studi Hukum Islam Konsentrasi Keuangan dan Perbankan Syari'ah, UIN Sunan Kalijaga, Yogyakarta, 2007).

Chapra, Umar. The Future of Economics: An Islamic Perspective, terj. Bustanus Saladin. Jakarta: SEBI, 2001.

Ghofur, Ruslan Abdul. "Mengembankan Ekonomi Kerakyatan: Beberapa Catatan tentang Praktik Lembaga Keuangan Syariah", dalam Kumpulan Makalah Dosen Perguruan Tinggi Islam Indonesia Peserta Program PETRII 2004-2006, ed. Generasi Baru Peneliti Muslim Indonesia. Jakarta: Australia-Indonesia institute, 2008.

Hasan, Zubairi Undang-undang Perbankan Syariah, Titik Temu Hukum Islam dan Hukum Nasional. Jakarta: PT. RajaGrafindo Persada, 2009.

Hasanuddin, Habib Nazir Muhammad. Ensiklopedi Ekonomi dan Perbankan Syariah. Bandung: Kafa Publishing, 2008.

Jurjânî, al-. al-Ta'rifât (Mesir: Musthafâ al-Bâbî al-Halabi wa Awladuhu, 1938.

Karim, Adiwarman Azwar. Bank Islam: Analisis Fiqih dan Keuaangan, edisi dua. Jakarta: PT. RajaGrafindo Persada, 2004.

Kuncoro dan Suharjono. Manajemen Perbankan Teori dan Aplikasi. Yogyakarta: BPFE UGM, 2002.

Lewis, Marvin K. dan Abgaoud, Latifa M. Perbankan Syariah, Prinsip, Praktik dan Prospek, terj. Burhan Subrata. Jakarta: Serambi Ilmu Semesta, 2007.

Majlis Ulama Indonesia. Himpunan Fatwa Dewan Syariah Nasional, Edisi Kedua. Jakarta: MUI, 2003.

Manzhûr, Ibn. Lisân al-Arab. Beirut: Dâr Lisân al-Arab, t.t.

Muallim, Amir. "Lima Aspek Ekonomi Islam yang Diragukan", dalam Menjawab Keraguan Ekonomi Syari'ah, ed. Amir Muaalim. Yogyakarta: Safiria Insania Press, 2008.

Muhammad. Manajemen Bank Syariah. Yogyakarta: PT. UUP AMP YKPN, 2005. 
Perwataatmadja, Karnaen A. Upaya Memurnikan Pelayanan Bank Syariah, Khusus Pembiayaan Murabahah dan Mudharabah di Indonesia. www.iqtishoduna.com. Diakses pada tanggal 30 Mei 2012.

Prabowo, Bagya Agung. Aspek Hukum Pembiayaan Murabahah pada Perbankan Syariah. Yogayakarta: UII Press, 2012.

Rahamawati, Naili. Mekanisme Pembiayaan Murabahah: WWW@yahooo.com. Diakses pada tanggal 19 Mei 2012.

Rahmawati, Naili. Mekanisme Pembiayaan Murabahah: http://williameaster.files.wordpress.com/2012/03/15_easterly _rahmawati_prp.pdf. diakses tanggal 15 Maret 2012.

Rahmawaty, Anita. Kontroversi Status Keabsahan Murabahah dalam Perbankan Syariah; Telaah atas Penerapan Produk di Bank Muamalah Semarang, (Tesis tidak diterbitkan) IAIN Sunan Kalijaga Yogyakarta, 2000.

Râzi, 'Abd al-Qadîr al-. Mukhtar al-Shihhah. Lebanon: Maktabah Lubnan Nâsyirûn 1995.

Rivai, Veithzal dan Permata Viethzal, Andria. Islamic Financial Management. Jakarta: Rajawali Press, 2008.

Seed, Abdullah. Menyoal Bank Syariah, terj. Sunan, cet. Ke-3. Jakarta: Paramadina, 2006.

Sjahdeini, Sutan Remy. Perbankkan Islam dan Kedudukannya dalam Tata Hukum Perbankan Indonesia. Jakarta: Pustaka Utama Grafiti, 1999.

Sudarsono, Heri. Bank dan Lembaga Keuanagan Syariah, Deskripsi dan Ilustrasi, edisi 3. Yogyakarta: Ekononisia, 2008.

Suhendi, Edi. Figh Muamalah: Membahas Ekonomi Islam. Jakarta: Rajawali Press. 2002.

Sutan, Remy Sjahdeini. Perbankkan Islam dan Kedudukannya dalam Tata Hukum Perbankan Indonesia. Jakarta: Penerbit Pustaka Utama Grafiti, 1999.

Syafi'e, Muhammad Antonio. Bank Syariah: Dari Teori ke Praktik. Jakarta: Penerbit Gema Insani, 2001.

Syarbini, al. Muhammad, Mughnî Muhtâj. Mesir: Mathba'ah al-Bânî Halabi, 1933.

Syarkasi, al. Al-Mabsût. Lebanon: Mauqi al-Islâm, tt.

Vogel, Frank E. Hukum Keuangan Islam, Konsep, Teori dan Praktik, terj. Syahadah Karim. Bandung: Nusamedia, 2007. 
Wirawan, Lutfi. Murabahah Dalam Konstruk Fikih dan Aplikasinya di BMI Cabang Yogyakarta (Program Pascasarjana UIN Sunan Kalijaga, Yogyakarta, 2010)

Wiroso. Jual Beli Murabahah. Yogyakarta: UII Press, 2005.

Zuhayli, Wahbah al-. Al-Figh al-Islâmi wa Adillatuhu, cet. I, jilid. V. Beirut: Dâr al-Fikr, 1997.

Zuhayli, Wahbah al-. Al-Mu'âmalat al-Mâliyat al-Mu'âsyirah. Beirut: Dâr Fikr, 2002. 